\title{
Research on Education Evaluation of Business English Talents Training in the New Era
}

\author{
Xiaomei Wang ${ }^{1, *}$

\begin{abstract}
${ }^{1}$ College of Applied Science and Technology, Beijing Union University, Beijing, 100101, China
\end{abstract} \\ *Corresponding author. Email:ldtwangxiaomei@buu.edu.cn
}

\begin{abstract}
In order to comprehensively reflect education quality and improve teaching effectiveness, this paper introduces comprehensive evaluation methods integrated by formative evaluation, summative evaluation and value-added evaluation into the education evaluation of Business English talents training. A multidimensional education evaluation system is established and weights of indexes are set according to the characteristics of Business English major; students' learning process is tracked and recorded on online teaching platform, and a value-added evaluation database is created by employing big data technology. In teaching practice, the evaluation system comprehensively shows students' mastery knowledge in 6 aspects, their efforts and improvements. It is also found that students have improved a lot in 5 aspects in the new model, through the value-added evaluation, it is found that the students' performance improvement is $8.9 \%$ higher than the class average score improvement. Applying the proposed comprehensive evaluation system in Business English talents training not only can comprehensively assess the teaching effectiveness, but also provide students with personalized guidance and stimulate their learning motivation and interests.
\end{abstract}

Keywords: business English, education evaluation, formative evaluation, value-added evaluation

\section{INTRODUCTION}

Business English is an English language used in commerce and industry with English as the carrier of information transmission. Business English major integrates professional knowledge of international trade, international business and foreign-related management with English language, aims to serve the regional economic, social and cultural development and achieve international exchange, and cultivates senior technical complex specialists who can adapt to the changes and needs of commercial activities. The cultivation of business English talents takes comprehensive English language performance as the base and business operation ability as the core. In the new era, new technologies, industries and business models have put forward new requirements for business English talents cultivation. It is a challenge for all business English teachers to face and deal with such new changes and requirements [1].

Education evaluation is an essential part of the education quality assurance system [2]. Student academic evaluation, as an important measure of student performance and an important element in assessing the quality of education, is the basis for promoting student development and improving the quality of education. Countries in Europe and America, and Japan have targeted education evaluation on improving school level and improving teaching quality. In the United States, the National Education Evaluation Center was established, and evaluation emphasis is put on students' learning experiences and outcomes; in Japan, higher education evaluation focuses on students' learning outcomes, with special emphasis on the overall assessment of students' development in terms of the degree of knowledge mastery, the degree of ability improvement and the depth and breadth of experience. In formative assessment process, evidence of students' learning progress is collected in the teaching and learning process to guide teachers, students, and learning peers in the next step of teaching or learning [3]. Talents training for business English major should follow the laws of education, improve result evaluation, strengthen formative evaluation, explore value-added evaluation, perfect comprehensive evaluation, and establish a scientific educational evaluation system that meets the requirements of the new era.

\section{THEORETICAL FOUNDATIONS OF EDUCATIONAL EVALUATION}

\subsection{Taylor's Educational Evaluation Theory}

Taylor devised the goal-cored learning evaluation to help Ohio State University faculty improve the evaluation of undergraduate from 1929 to 1934 . Taylor proposed that educational assessment was a process to discover what students have learned and the value it holds, i.e., educational evaluation is the process of determining to what extent educational goals are actually achieved [4]. Accordingly, Taylor put forward education goal-cored evaluation theory, and explicitly introduced the concept of 
educational evaluation, thus distinguishing educational evaluation from educational measurement. Taylor's educational evaluation theory is based on Thorndike, Dewey and Judd, all of whom regard educational research as a science and emphasize cultivating students' scientific inquiry ability and the ability to use scientific methods. Theoretically, Taylor's goal-cored evaluation theory inherited Thorndike's idea of taking educational research as a science, and accepted Dewey's view that education means growth. Therefore, Taylor's educational evaluation theory emphasizes measuring and evaluating students' continuous growth and learning process. In addition, Taylor was influenced by Judd and brought psychological ideas into educational evaluation research.

The basic ideas of Taylor's educational evaluation theory are: (1) education is the process of changing students' ways of action; (2) educational goals are changes in various ways of action; (3) the so-called educational evaluation is the process of determining to what degree the educational goals are achieved; (4) students' actions are complex, so evaluation should be conducted from all aspects, and it is not only analytical but also comprehensive. According to Taylor, educational goals essentially refer to changes in students, and therefore evaluation is the process of determining the degree of behavior change that actually occurs. Educational evaluation means assessing student behavior, and at all times evaluation must include more than one assessment to confirm that behavior is actually changing.

\subsection{Value-added Evaluation Theory}

In 1966, James Coleman submitted the "Equality of Educational Opportunity" report to the U.S. Congress, known as the Coleman Report. The report gave new meaning to equality of educational opportunity, meanwhile, it emphasized the important influence of family background on students' academic achievement, thus prompting a re-examination of the evaluation criteria for school effectiveness. Research on value-added evaluation theory began to sprout. In the following decades, a number of countries have conducted practical explorations and pushed the research on value-added evaluation theory to maturity [5] [6]. Value-added evaluation takes uncontrollable factors such as the student's previous level and family background into account, compares longitudinally students' performance after they have been educated for a period of time, and evaluates students based on the degree of improvement in various aspects, and obtains the degree of influence of the school and teachers on their progress, so as to make a reasonable evaluation of school effectiveness and teacher effectiveness. Value-added evaluation focuses on students' academic performance and is a type of student evaluation. The value-added evaluation is a longitudinal comparison of a student's performance over a period of time in order to grasp the student's progress and make a value judgment on his or her academic performance. Value-added evaluation emphasizes the nature of evaluation, emphasizes development, pays more attention to students' potential, and takes students' academic progress as judging criterion. It plays an orientation and motivation function, guides students to be active and aggressive, cultivates students' self-confidence, and encourages them to make further efforts toward their goals, so as to promote students development [7].

\section{EVALUATION SYSTEM OF BUSINESS ENGLISH TALENTS TRAINING}

Education evaluation of business English talents training should be based on the characteristics of business English teaching and students' learning situation, focus on core outcomes, adopt various flexible and diversified composite assessment methods, and choose the standard that best meets students' learning situation, so as to truly promote learning and teaching, to ensure that all students have a sense of accomplishment and a strong desire to learn.

Firstly, the use of formative evaluation in business English talents training is determined by the characteristics of business English itself. As one of the special-purpose English, business English is a typical language used in business workplace with English language as the carrier. The most important features of business English include its social and communicative functions, so the teaching of business English should focus on both language learning and skill drilling. Business meetings, business negotiations, business presentations, business phone calls conversations, etc. are the basic forms of business English training. Students are required to do a lot of practice and drilling in language learning process, not just memorization words and phrases. So it is critical to simulate real business scenarios and design and organize different kinds of group activities according to different business segments in real workplace. Formative evaluation helps to break down the whole learning process into separate business segment. Business English education evaluation strengthens formative evaluation. It is necessary to strengthen the evaluation in the process, i.e., conducting multiple educational evaluations by recording and collecting students' behaviors and works in learning process, such as students' learning motivation, learning methods, independent learning ability, as well as questions and answers, discussion and group activities in classroom. The diversified evaluation of business English talents training is shown in Fig.1. Process evaluation should be emphasized, that is, making scientific and accurate analysis of students behaviors, works and other process performance.

During teaching and learning process, classroom activities are the main basis for teachers to observe students' learning performance and evaluate their language application ability and communication skills. Feedback on students' classroom performance is provided to students through face-to-face or written communication, and suggestions for improvement are made. Meanwhile, classroom observation also includes observing students' evaluation on classroom organization, which helps teachers improve and perfect teaching contents 
and activities. Black and William, British assessment experts, stated in Classroom Learning and Assessment that through analysis of 250 research findings on assessment they drew the conclusion: compared with staged examinations, formative assessments such as questions and answers, discussions, and post-class feedback in teachers' classrooms are more helpful to students' learning and more helpful in improving their learning outcomes [8]. Evaluating students' performance or assignments, communicating their learning progress, and guiding them on how to achieve their learning goals have significant positive effects on facilitating learning. Many studies have demonstrated the significant benefits of effective feedback in promoting learning and have also defined what constitutes quality feedback. The most effective feedback is based on assessment criteria and provides specific suggestions about how well the task itself was completed and how it can be improved [9].

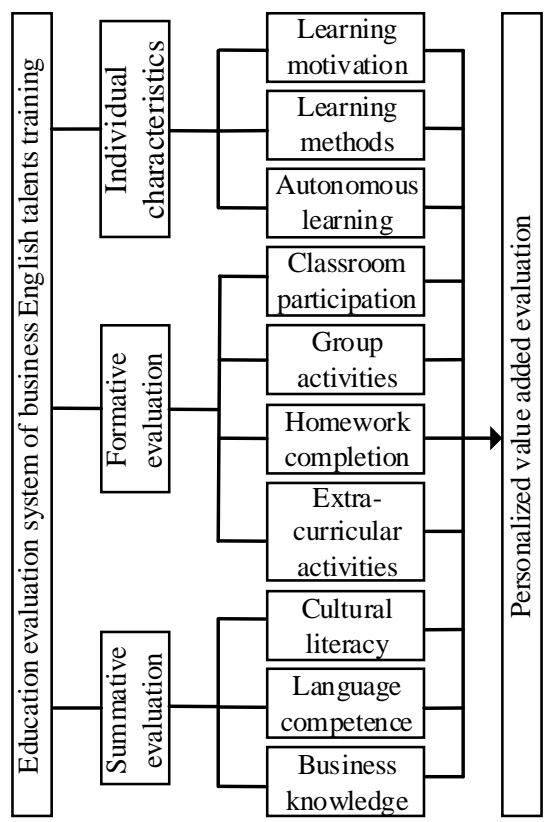

Figure 1. Multivariate evaluation of student course learning

Secondly, employing value-added evaluation in business English talents training is essential in promoting personalized learning for students. Compared with summative and formative evaluation, value-added evaluation is a concept of longitudinal comparative evaluation of students' own learning. Value-added evaluation changes the tendency that emphasizes input rather than process and selection rather than cultivation, and shifts to focus on education process and students' personalized development. By measuring students' learning at different points and recording their progress, valueadded evaluation provides targeted feedback to teachers and school management departments, thereby improving teaching and management qualities. With development as the essence and personalization as the core, value-added evaluation changes traditional horizontal data comparison and adopts vertical comparison of individual students' achievements, which better promotes students personalized development. Value-added assessment helps advanced students consistently record their progress; progress means value-added, indicating that students have improved with effort, and the positive assessment helps them gain confidence and intrinsic motivation. Exploring value-added evaluation helps reduce the influence of such external conditions as student quality, faculty, and school conditions on educational assessment results.

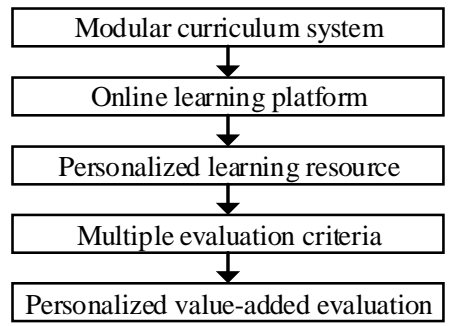

Figure 2. Personalized value-added evaluation of business English talents training

Employing online teaching platforms and modern teaching methods can stimulate students' interest in business English courses. Personalized value-added evaluation of business English talents training is shown in Fig.2. It is urgent to establish a value-added database of students' value-added evaluation system by expanding the learning space and making full use of big data technology. The value-added database brings together, integrates, and analyzes data on students' selected courses, learning situations (test scores, examination performance, and daily evaluation), and credits earned, records what students have completed and the degree of learning they have achieved each time, and, through vertical accumulation, obtains the extent of students' progress each time in order to achieve individual academic evaluation and individual development monitoring. Once the value-added database is established, it not only helps to understand the learning situation of individual students and make personalized value-added evaluation and appropriate development planning for them, but also helps to understand the teaching effectiveness of the whole school and provide reference for curriculum reform, teaching improvement and teacher training.In order to better meet students' personalized needs, the study has established a modular curriculum system for business English, as shown in Tab.1. In the curriculum system, a more sound and open, scientific and reasonable credit system is set up. So students can freely choose the courses they interest, and participate in the learning evaluation process as a relevant stakeholder, which is conducive to guaranteeing students more autonomy in learning and evaluation, so that they can master the development initiative and stimulate their own potential development.

Value-added evaluation of business English talents training focuses on potential and stimulates development, takes students' unique development needs into full consideration, adapts to the characteristics of students in vocational colleges. To a certain extent it makes up for the shortcomings of traditional evaluation methods. Traditional 
student academic evaluation transposes a set of evaluation standards adopted in the field of general education to the field of vocational education, and assesses students based on test scores, which overemphasizes the screening function of evaluation, increases students' psychological burden, strengthens their failure experience, discourages their learning.

Table 1. Curriculum System for Business English Major

\begin{tabular}{|c|c|c|}
\hline Course Module & Module Function & Proportion \\
\hline $\begin{array}{l}\text { English } \\
\text { Language }\end{array}$ & $\begin{array}{l}\text { Cultivate English } \\
\text { language basic skills: } \\
\text { listening, speaking, } \\
\text { reading, writing and } \\
\text { translating }\end{array}$ & $30 \%$ \\
\hline Business & $\begin{array}{l}\text { Cultivate business } \\
\text { communicative } \\
\text { competence in } \\
\text { business context }\end{array}$ & $35 \%$ \\
\hline Culture & $\begin{array}{l}\text { develop intercultural } \\
\text { communicative } \\
\text { competence }\end{array}$ & $25 \%$ \\
\hline Certificate & $\begin{array}{l}\text { Develop business } \\
\text { English practical } \\
\text { application ability }\end{array}$ & $10 \%$ \\
\hline
\end{tabular}

Thirdly, educational evaluation of business English talents training should shift from summative evaluation to formative evaluation that attaches importance to the teaching and learning process, should integrate multiple evaluation subjects, multiple evaluation methods, diverse evaluation contents and multiple types of evaluation results. Diagnostic function of process evaluation should be emphasized; timely diagnostic feedback on the process of teaching and management should be made; timely adjustments to educational goals should be made; timely reference for education decision-making should be made. It is urgent to explore value-added evaluation, giving priority to the education process and student development, focusing on the magnitude of educational progress and efforts of students and teachers, and providing targeted feedback on teachers' teaching, school management and government governance, so as to improve overall equity and quality of education. Sound comprehensive evaluation means diversity of evaluation content. Evaluation should be made in all aspects. Comprehensive assessment results and comprehensive quality assessment should be made. Evaluation method should focus on innovation of education evaluation theory and technology, aiming to promote diversification of education evaluation methods. For evaluation subjects, a diversified education evaluation system with multiple participation of teachers, students and third parties is recommended.

\section{PRACTICE OF EDUCATION EVALUATION IN BUSINESS ENGLISH TALENTS TRAINING}

The evaluation system proposed in the study combines formative and summative evaluation. A diversified and multidimensional course evaluation system is established a rating scale is used, i.e., a series of evaluation indicators such as independent learning, class participation, group activities, completion of homework, extracurricular activities, and summative tests are set according to different weights, as shown in Tab.2.

Table 2. Evaluation System of Business English Talents Training

\begin{tabular}{|c|c|c|}
\hline No. & $\begin{array}{c}\text { Primary } \\
\text { Indicators and } \\
\text { Weights }\end{array}$ & Primary Indicators and Weights \\
\hline 1 & \multirow{3}{*}{$\begin{array}{c}\text { Individual } \\
\text { Characteristics } \\
10 \%\end{array}$} & Learning Motivation 20\% \\
\hline 2 & & Learning Methods $30 \%$ \\
\hline 3 & & Autonomous Learning $50 \%$ \\
\hline 4 & \multirow{4}{*}{$\begin{array}{c}\text { Formative } \\
\text { Evaluation } \\
\quad 40 \%\end{array}$} & Participation in Class $30 \%$ \\
\hline 5 & & Group Activities $30 \%$ \\
\hline 6 & & Homework completion $30 \%$ \\
\hline 7 & & Extra-curricular Activities $10 \%$ \\
\hline 8 & \multirow{3}{*}{$\begin{array}{l}\text { Summative } \\
\text { Evaluation } \\
50 \%\end{array}$} & Culture Literacy $20 \%$ \\
\hline 9 & & Language Competence $40 \%$ \\
\hline 10 & & Business Knowledge $40 \%$ \\
\hline
\end{tabular}

Each indicator is evaluated according to the merits of performance, such as excellent, good, fair and poor. The system includes diversified evaluation subjects, including students, teachers, employers and other evaluation subjects, to overcome the limitations and subjectivity of a single evaluation subject, to ensure the fairness and impartiality of the evaluation results. Characteristics of the evaluation system lie in the combination of summative and formative evaluation, the combination of qualitative and quantitative evaluation, diversification of evaluation contents, evaluation subjects and evaluation tools.

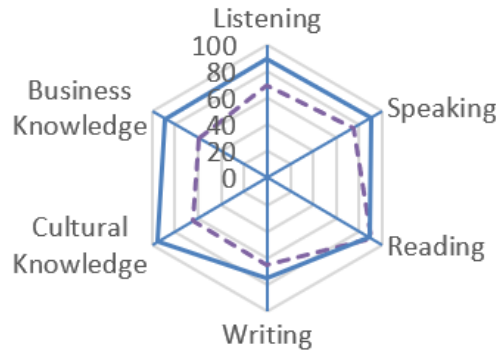

Figure 3. Multidimensional evaluation of students' business English Course Learning

In the evaluation system, course learning effectiveness evaluation is subdivided into such dimensions as listening comprehension, oral expression, reading comprehension, 
writing, cultural literacy and business knowledge, etc. Test scores are shown in Fig. 3, with the dotted line indicating the first test scores and the solid line indicating the second. Fig.3 shows that students' second test scores have improved in all five dimensions compared to the first test, except for writing. This multidimensional comparative evaluation shows students' mastery knowledge in all aspects, and their efforts and improvements.

Students' test scores for business English courses are also compared in the study, as shown in Fig.4. Students' scores increased from 70.8 to 88 , while the average score of the class increased from 78 to 90 . Although students' academic performance has not yet reached the class average, the students' score increased $8.9 \%$ quicker than class average, indicating that the student's academic progress was faster than the average progress of the entire class.

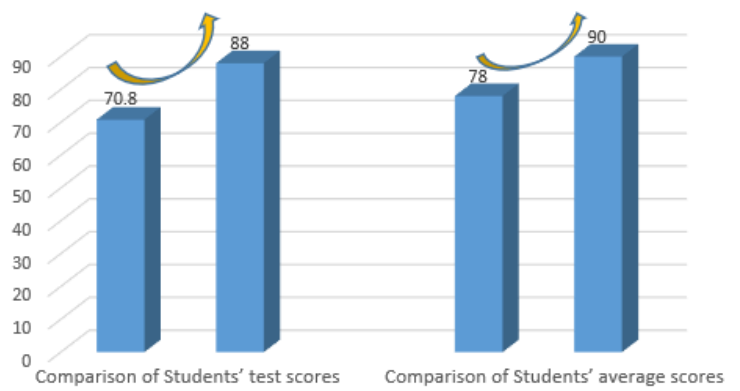

Figure 4. Comparison of students' learning effects of business English courses

Value-added evaluation is based on the principle of individuality and focuses on students' needs as unique individual, and takes the approach of longitudinal comparison of individual before and after performance to make value judgments on students' academic performance. It does not require all students to reach the same level, but focuses on the added-value of individual, fully considers the difference of each student's starting point, fully respects the differences of each student in various aspects, and helps students advance at their own pace. In the practice, it is found that students' success experience has been greatly strengthened, that students' improving self-efficacy and confidence has been greatly improved, that students' learning motivation has greatly stimulated. Most of students has ultimately attained academic achievement and individualized development in practice in the study project.

\section{CONCLUSION}

The most important features of business English include its social and communicative functions, so business English should be taught with equal emphasis on language learning and skills application. The characteristics of business English require a comprehensive evaluation mechanism to truly reflect the quality of teaching and learning. A scientific educational evaluation mechanism not only can assess the quality of students' learning, knowledge and skills, guide students' learning actions, strengthen their motivation, improve their learning methods and skills, stimulate their interest in learning, increase their participation and enhance their professional competence, but also help teachers to obtain timely feedback, improve teaching management and enhance teaching standards and quality. Formative evaluation, summative evaluation and value-added evaluation are interrelated and mutually complementary, the three making up a comprehensive education evaluation system. In business English talents training, it is urgent to strengthen process evaluation, explore value-added evaluation, and improve comprehensive evaluation to cultivate business English professionals who meet the requirements of the new era

\section{ACKNOWLEDGMENT}

This study was supported by a grant of Education Science Research Project "Research Learning-Centered English Classroom Teaching Model in Higher Vocational College" (No.Jk201908) supported by Beijing Union University.

\section{REFERENCES}

[1] E. Tour, "Digital mindsets: Teachers' technology use in personal life and teaching," Language Learning \& Technology, 2015, vol.9, pp. 124-139.

[2] Haixia Xu, Rui Wang, and Luting Ma, "Several Key Issues of Education Evaluation Reform," China Examination, 2020, vol.8, pp.20-23. (In Chinese) DOI: 10.19360/j.cnki.11-3303/g4.2020.08.005

[3] P. Black, and D. William, "Developing the Theory of Formative Assessment," Educational Assessment, Evaluation and Accountability, 2009, vol.1, pp.5-31. http://dx.doi.org/10.1007/s11092-008-9068-5

[4] R. W. Tyler, "Basic Principles Curriculum and Instruction, 1st ed.," Chicago, IL: University of Chicago Press, 2013. http://dx.doi.org/10.7208/chicago/

\subsection{1 .0001}

[5] A. Kelly, and C. Downey, "Value-added measures for schools in England: Looking inside the "black box" of complex metrics," Educational Assessment, Evaluation and Accountability, 2010, vol.22, pp.181198.

[6] A. C. Timmermans, and S. M. Thomas, "The impact of student composition on schools' value-added performance: a comparison of seven empirical studies," School Effectiveness \& School Improvement, 2015, vol.3, pp.487-498.

[7] Yunlong Chen, "Study on Value-added Evaluation of Talents Training Quality in Higher Education," Education Review, 2019, vol.9, pp.30-34. (In Chinese) 
[8] P. Black, and D. William, "Inside the Black Box: Raising Standards through Classroom Assessment," The Phi Delta Kappan, 1998, vol.2, pp. 139-148.

[9] J. Hattie, and H. Timperley, "The Power of Feedback," Review of Educational Research, 2007, vol.1, pp.81-112.

http://dx.doi.org/10.3102/003465430298487 